\title{
16 Nisan 2017 Anayasa Değişikliği Referandumu Örneğinde İletişim Fakültesi Öğrencilerinin Oy Verme Kararlarında Seçim Mecralarının Etkisi
}

\author{
The Effects of the Election Mediums on Voting Decisions of the School of Communication \\ Students: The Example of the Constitutional Referendum Held on 16th April, 2017
}

\section{Metin IŞIK ${ }^{*}$ K. Özkan ERTÜRK ${ }^{* *}$ Elif ŞEŞEN ${ }^{* * *}$}

\section{Öz}

Siyasal kararlara katılım demokratik yapının gerekliliği olarak modern toplumların gündeminde önem arz eden bir olgudur. Siyasal katılımın ilk akla gelen şekli olan oy verme davranışı, toplum içerisinde bireyin sosyoekonomik ve sosyal psikolojik süreçlerinden etkilenmektedir. Bu süreci etkileyen bir başka önemli öğe de kitle iletişim araçlarıdır. Zira temsili demokrasilerin hakim olduğu günümüz modern toplumlarında, bilgisayar ve internet teknolojilerinde kaydedilen ilerlemeler, bilginin zaman ve uzam içerisindeki dolaşımını artırarak şekillendirmekte ve bu durum bireyin kamusal olaylara bakışı üzerinde de etkili olabilmektedir. Siyaset ile iletişimin birleşiminden doğan ve bu iki alanın birbirinden ayrılmasını gittikçe güçleştiren siyasal iletişimin, kitle iletişim araçlarına bağımlı bir görünüm arz ettiği söylenebilir. Bu çalışma, aldıkları eğitimle gelecekte bu alana yön vermeleri beklenen iletişim fakültesi öğrencilerinin siyasal gündem takibi ve oy verme davranışlarını ortaya koymayı amaçlamaktadır. 16 Nisan 2017 Anayasa Değişikliği Referandumu örneğinde iletişim fakültesi öğrencilerinin medya kullanım alışkanlıkları ile oy verme davranışı arasındaki ilişki üzerine gerçekleștirilen bu çalışmada iletişim mecralarının öğrencilerin siyasal kararlara katılımına etkisinin sınırlı kaldığı sonucuna ulaşılmıştır.

Anahtar Kelimeler: Referandum, Siyasal İletişim, Oy Verme, Politik Gündem Takibi, Anayasa Değişikliği

* Prof. Dr., Sakarya Üniversitesi İletişim Fakültesi, Sakarya, Türkiye, imetin@sakarya.edu.tr Orcid ID: 0000-0001-5984-0328

** Prof. Dr., Düzce Üniversitesi, Sanat,Tasarım ve Mimarlık Fakültesi, Düzce, Türkiye, ozkanerturk@mynet.com Orcid ID: 0000-0003-0804-3470

*** Dr. Öğr. Üye., Niğde Ömer Halisdemir Üniversitesi, İletişim Fakültesi, Niğde, Türkiye, elifsesen@gmail.com, Orcid ID: 0000-0002-8513-9647 


\begin{abstract}
Participation in political decisions as the necessity of the democratic structure, is an important issue in the agenda of modern societies. Voting behavior which is the first form that comes to mind of political participation, has been influenced by the individual's socioeconomic and social psychological processes in the society. One of the most important factor affecting this process is the mass media. In modern democracies, progress in computer and the Internet technologies increases the circulation of information in time and space, which can affect the individual's view and thought about public issues. It can be said that the political communication that emerged as a result of the combination of politics and communication and which is getting more and more difficult to separate these two fields has become dependent on mass media. This study aims to reveal the politic agenda following and voting behaviors of communication faculty students who are expected to lead this field in the future with their education. In this study which was conducted to examine the relationship between the media usage habits of school of communication students and voting behaviors in the example of the 16th April Constitutional Referendum, has been concluded that the influence of communication mediums on the participation of students in political decisions is limited.
\end{abstract}

Keywords: Referendum, Political Communication, Voting, Politic Agenda Following, Constitutional Amendment

\title{
Giriş
}

Siyasal kararlara katılma, diğer bir deyişle bireyin siyasal tercihlerini ifade etmesi, sosyal bir varlık olarak insanın toplum içerisindeki konumlanışıyla yakından ilgilidir. Bireyin yakın çevresi ve bu toplumsal çevre ile iletişim biçimi, geçmiş tecrübeleri, yaşam şekli, aile yapısı ve eğitim süreci siyasal kararlara katılım tercihini etkilemektedir. Siyasal katılım sürecinde kitle iletişim araçları, bireyin bilgi düzeyi ve olayları anlamlandırmasında etkili olmaktadır. Süreç içerisinde kitle iletişim araçlarını vazgeçilmez kılan, yazılı-basılı ya da sesli-görüntülü materyalle işlenmiş iletiyi, dünyanın her yerindeki bireye ulaştırabilmesi; en zayıf, en mahrem anında bile onu yakalayabilmesi ve bu sayede bireyi hem fert olarak hem de içinde bulunduğu sosyal çevresiyle birlikte etkilemesidir (Anık, 2000, s. 58).

Günümüzde siyasal iletişimin, kitle iletişim araçlarına bağımlı bir görünüm sergilediğini söylemek mümkündür. Siyasal iletişim açısından adaylara ya da partilere sempati duyan seçmenlere etkin ve kullanılabilir bilgi iletilmesinin önemini ve değerini vurgulayan Trent ve Friedenberg (1983), siyasal iletişim sürecinin yönlendirilmesinde kitle iletişiminin önemli bir rol oynadığını söylemektedirler. Yönetenler ve yönetilenler arasında fikir, etki ve bilgi akışını, bir başka deyişle iletişimi sağlayan birimler olarak kitle iletişim araçları yaşamsal bir öneme sahiptirler.

Temsili demokrasilerin vazgeçilmez ve ayrılmaz bir parçası olarak kabul edilen seçimler, siyasal sistem içinde yöneten-yönetilen arasındaki iletişimi sağlamakta ve siyasetçilere politikaları ve uygulamalarıyla ilgili seçmenlerin tepkilerini ulaştıran bir geri besleme süreci olarak işlemektedir 
(Cotteret ve Emeri, 1995). Seçim dönemlerinde vatandaşların, kampanya bilgilerini doğrudan adaylardan alması pek mümkün değildir. Kitle iletişim araçları bu süreçte başta gelen mecra niteliğindedir. Kişisel iletişim, söylentiler ya da kişilerarası görüşme ve tartışmalar aracılığı ile bilgi dolaşımında etkin bir rol oynar; ancak, seçmenlerin kendi aralarında yaptıkları tartışmaların ya da görüşmelerin temel konuları, haber medyasında yer alan öykülerden oluşur (Uztuğ, 2004). Seçim kampanyalarının yapıldığı süre içerisinde seçmenler etkilenmeye açık bir duruma gelir, medyanın etkileme oranı artar ve insanlar medyanın siyasal bilgilendirmesine göre davranışlarını değiştirebilirler (Güz, 1996, s. 986). Demokratik rejimlerde seçim dönemlerinde kamuoyunun ilgisini yoğunlaştırdığı kitle iletişim araçları, bu süreçte haber verme ve bilgi sağlamanın yanında, etkileme ve yönlendirme gücüne de sahiptir. Bu dönemlerde kitle iletişim araçları, gündemi takip edebilmek ve yeni gelişmelerden haberdar olabilmek adına toplumun büyük bir kesimi için temel iletişim mecrası niteliğindedir. Bu kesimlerden biri de gençlerdir.

Medyanın siyasal katılımı nasıl etkilediğine dair daha derin bir anlayış kazanmayı hedefleyen bu çalışmada, mevcut bulguların genişletilmesi amacıyla siyasal katılımın kuramsal boyutuna dair bilgi sahibi olduğu kabul edilen ve ayrıca teknolojiyi yoğun olarak kullanmakta olan bir kesim olarak üniversite öğrencileri hedef kitle olarak belirlenmiştir. Çalışmada 16 Nisan 2017 Anayasa Değişikliği Referandumu öncesi ve sonrasında iletişim fakültesi öğrencilerinin siyasal katılımları ile medya kullanımları arasındaki ilişki araştırılmıştır.

\section{Kitle İletişim Araçlarının Siyasal Katılıma Etkisi}

Siyasal katılım, liberal demokratik sistemlerin merkezi bir ilkesi ve vatandaşlık sorumluluğunun da önemli bir parçası olarak kabul edilmektedir. Demokratik kurumlar açısından, siyasal katılım tek bir kararın onaylanması ya da bir bütün olarak politik sistemin desteklenmesini sağlayan bir mekanizmadır. Siyasal katılım kavramı, siyasal bilimciler için popülerliğini hep korumuş ve birçok araştırmaya konu olmuştur. Siyasal katılım "ya uygulanan kamu politikalarını etkileyerek doğrudan, ya da bu politikaları tasarlayan siyasal aktörlerin seçimini etkileyerek dolaylı olarak hükümet hareketlerini etkileyebilecek davranış”tır (Verba'dan aktaran Yamamoto, Kushin ve Dalisay, 2013, s. 4). Kate Kenski ve Natalie J. Stroud (2006) ise siyasal katılımı, "bir kampanyaya bağış yapma veya başkalarını oy kullanmaya ikna etme gibi siyasetle ilgili faaliyetlerde bulunma” olarak tanımlamaktadırlar (s. 174).

Siyasal katılımı bir siyasal davranış olarak ele alan Ersin Kalaycıoğlu’na (1983) göre siyasal katılım, "siyasal sistem içerisinde yer alan bireylerin, siyasal karar vericilerin aldıkları kararların niteliklerini etkileyebilmek üzere ortaya koydukları davranış ve faaliyetleri” ifade etmektedir (s. 9). Mustafa Aydın’a (2006) göre ise siyasal katılım, "yönetilenlerin yönetim sürecine etkileri” olarak anlaşılabilir (s. 172).

İlter Turan (1986), siyaset olgusunu ve siyasal katılımı daha iyi anlayabilmek için kişilerin, siyasal olana duydukları ilgi, siyasal olana ilişkin bilgi düzeyleri ve siyasal tutumlarının göz önünde tutulması gerektiğini söylemektedir (s. 67). Aslında siyasal katılımın çok farklı yolları vardır ancak klasik demokrasi anlayışıyla özdeşleşen ve ilk akla gelen oy kullanmadır. Siyasal davranışın bir alt 
eylemi olarak oy verme, sosyoekonomik (yaş, gelir, meslek, cinsiyet, eğitim, yerleşim) ve psikolojik etmenlerden etkilenerek, siyasal kültür ve siyasal toplumsallaşma içinde biçimlenir (Sarıbay, 1994). Siyasal katılımın azaldığına dair araştırma sonuçları dikkate alındığında vatandaşları katılım için harekete geçmeye nelerin teşvik ettiğini anlamak daha önemli hale gelmiştir (Martin, 2012). Siyasal katılım; mitinglere katılma, politikacılarla doğrudan temas kurma, oy verme gibi geleneksel yolların yanı sıra dijital teknolojiler vasitasıyla karar vericileri etkilemeye yönelik geleneksel olmayan yolları da kapsamaktadır. Çeşitli araştırmalardan elde edilen sonuçlar, oy kullanmanın hala temel siyasal katılım şekli olduğunu göstermekle birlikte, bu geleneksel davranışın büyük oranda geleneksel olmayan katılım yolları ve araçlarının etkisiyle biçimlendiğini göstermektedir.

Demokratik rejimlerde siyasal kararlara katılım her ne kadar özünde bireysel bir davranış olan oy verme ile nihayete ermiş olsa da, bireyin kararlarında içinde bulunduğu yakın ve uzak çevreyle bilgilenme düzeyi ve yönlendirmeler de etkili olabilmektedir. Bu noktada bireyin kararları üzerinde değer verdiği ya da vermediği, dikkate aldığı ya da almadığı birçok kişi ve farklı odaklardan edindiği bilgiler etkili olabilmektedir. Michael X. Delli Carpini ve Scott Keeter (1996) siyasal bilginin oy kullanma olasılığı üzerinde güçlü bir etki yarattı̆̆ı sonucuna ulaşmışlardır. Nakwon Jung, Yonghwan Kim ve Homero Gil de Zúñigảnın (2011) araştırması da siyasal bilginin siyasal katılımı önemli ölçüde etkilediğini göstermektedir. Charles Atkin ve Gary Heald’a (1976) göre ise, politik haber ve bilgiye ilgi gösteren kişilerin bir seçimde oy kullanacaklarına dair beklenti de artmaktadır (s. 218). Bir başka deyişle, siyasal katılıma ilk adım, siyasal konulara ilgi göstermektir. Bu bakımdan siyasal katılım açısından medyada bilgi arayışı önemli bir etkendir. Çünkü geleneksel toplum yapısında çözülmelere yol açan değişme ve gelişme süreçlerinde görülen, seçmenin yalnızlaşarak evinde yalıtılmış olması durumu medyanın, siyasal konularda bilgi edinmede daha önemli hale gelmesine yol açmıştır (Ylldız, 2002, s. 104).

Demokrasi ile yönetilen ülkelerde medya, toplumu bilgilendirme, demokrasi kültürünü yerleştirme, gündemdeki kamusal tartışma konularıyla ilgili duyarlılığı artırarak katılımı sağlama ve toplumsal seferberliği geliştirme gibi önemli işlevler üstlenmektedir (Damlapınar ve Balc1, 2014, s. 56). İletişim araçları bu işlevlerini yerine getirirken aynı zamanda biçim ve içeriklerine bağlı olarak bir takım toplumsal süreçlere de etki etmektedir. Siyasal tercihler de toplumun büyük bir bölümünün zaman zaman gündemini meşgul eden önemli bir olgu olarak karşımıza çıkmaktadır. Zaman içerisinde demokrasinin gelişerek kurumsallaşması, siyasal tercihin toplumsal rolünü artırması, oy verme davranışının da giderek daha büyük bir öneme sahip olup kamuoyunun büyük bir bölümünün ilgisini çekmesi sonucunu ortaya çıkarmıştır. Kitle iletişim araçları, taraflı olsun ya da olmasın bir biçimde ilettiği bilgilerle siyasal süreçlerde etkili olmaktadır. Nitekim, Oya Tokgöz’ün (1978) de belirttiği gibi, "Siyasal dünya hakkındaki bilgiler, medya yoluyla ikinci el gerçekler olarak bireylere ulaştırılmaktadır. Kişiler, bu araçlardan toplumda yaygınlıkları ölçüsünde ve kişisel alışkanlıklarına göre yararlanmaktadırlar” (s. 80). Kitle iletişim araçlarının dünyaya ilişkin imgeleri biçimlendirme gücü, medya-siyasal davranış ilişkisinin önemli bir boyutunu oluşturmaktadır. Kitle iletişim araçları ya da kısaca medyanın, modern insanın dünyaya ilişkin imgelerini yaratmasına katkıda bulunduğuna dikkat çeken Knut Lundby ve Helge Ronning (1997), medyayı yurttaşların bazı kamusal sorunları ve bazı 
temel değerleri, tartışma ve söylem yoluyla inşa ettikleri ve dolayısıyla toplumsal, kültürel ve siyasal temsiliyete aracı yapılar olarak tanımlamaktadırlar (s. 19).

Günümüzde siyasal bilginin mevcut ve potansiyel seçmenlere aktarılmasında kitle iletişim araçları ve bu araçlar içinde de internet öncelikli bir yere sahiptir. Bugün uydu teknolojileri sayesinde coğrafi şartlar dolayısıyla ulaşımı zor olan bölgelerde vatandaşlarla bilgi alışverişinde internet ve sosyal ağlar büyük önem taşımaktadır (Chun, Shulman, Sandoval ve Hovy, 2010, s. 3). Milyarlarca insanın kullandığ 1 internet, eğlence aracı olmanın ötesinde insanların bilgiye olan ihtiyacını karşılayan bir kitle iletişim aracı olarak işlev görmektedir (Tongut ve Akman, 2014, s. 121). İnternet, sosyal ve politik davranış için geniş fırsatlar sunan yeni bir kamusal çevre inşa etmektedir (Shah, Kwak ve Holbert, 2001; Stanley ve Weare, 2004). Siyasal tercihlerin ifade edilmesinde, pekiştirilmesinde ve yaygınlaştırılmasında siyasi parti ve liderlerce başvurulan temel araçlardan biri halini alan sosyal medyanın siyasi katılımı ve tartışmayı artırma potansiyelini kullanan bireyler, siyasal partileri ya da liderleri takip etmenin yanı sıra birbirleriyle de siyasal konularda etkileşimler gerçekleştirebilmektedirler (Bayraktutan vd., 2014, s. 60). Siyasal tercihlere katılım sürecinde internet, siyasete katılım için online seçim anketleri, tartışmalar, bloglar ve sosyal ağlar gibi yeni fırsatlar sunmaktadır. Lynda L. Kaid ve Christina Holtz-Bacha'ya (2008) göre bloglar, podcastlar, online katılımı ve geri bildirim almayı sağlayan siyasi web siteleri, sosyal ağlar ve online video paylaşımı gibi online araçlar siyasal iletişim sürecinde önemli bir role sahiptir. Ancak yeni medyanın seçim kampanyalarının başarısı ya da başarısızlığına etkisi henüz tam olarak ölçülememiş olup araştırmalarda çelişkili sonuçlara ulaşılmıştır (Fama ve Tam, 2010, s. 85). Siyasal karar alma sürecinde kitle iletişim araçlarının rolü üzerine çeşitli araştırmalar yapılmıştır. Örneğin Baki Can’a (2005) göre seçimler öncesinde vatandaşların adaylar hakkında bilgi edindikleri kaynaklar arasında medya ilk sırada yer almakta, medyayı aile ve arkadaşlar takip etmektedir. Karin Gwin Wilkins (2000) de haber takibinde televizyon ile gazete kullanım oranlarının benzer olduğunu ve siyasal katılımla pozitif ilişkili olduğunu göstermektedir. Adem Doğan ve Göksel Göker'in (2013) çalışması adayların televizyondaki konuşmaları ile çeşitli programlardaki performanslarının seçmenlerin siyasi tercihlerini etkilediği yönündedir. Saiful Mujani ve R. William Liddle’ın (2010) çalışmasının sonuçlarına göre ise seçmenler seçim kampanyası sırasında haberleri, ilk olarak televizyondan (\% 88.8), daha sonra gazeteden (\% 34,9) ve internetten (\% 30) almaktadırlar. Nurettin Güz'ün (1995) çalışmasına göre de televizyon, seçmenin oy verme kararı sürecinde başvurduğu kitle iletişim araçları arasında ilk sırada gelirken radyo son sıralarda yer almaktadır. Ahmet Kalender'in (2003), Zülfikar Damlapınar ve Şükrü Balcı’nın (2005), Şükrü Balcı ve Hüsamettin Akar’ın (2010) ve Süleyman Karaçor'un (2013) çalışmaları da televizyonun ilk sırada gelen bilgi edinme aracı olduğunu göstermektedir. Gazete, televizyonu takip ederken seçim afişleri son sırada gelmektedir.

\section{Gençler ve Siyasal Katılım}

Siyasal katılım ve bu katılımın görünen yüzü olan oy vermede yaş, cinsiyet ve eğitim etkili faktörler olarak öne çıkmaktadır. Nancy Burns, Kay Lehman Schlozman ve Sidney Verba (2001) politik katılımda bireyler arasındaki farkın temel nedenini katılma talebi eksikliğine bağlamakta 
ve bu talebin oluşması için kişinin bazı kaynaklara sahip olması gerektiğini vurgulamaktadırlar. Henry E. Brady, Sidney Verba ve Kay Lehman (1995) bu kaynakları zaman, para ve beceri olarak saymaktadır. Bunlardan zaman, politik eylem ve toplantılara katılabilmek için boş/uygun zamana sahip olmayl; para politik katılıma maddi destekte bulunabilmeyi; beceri ise politik süreci anlamak ya da politik amaçlı iletişimde bulunmak gibi katılım için ihtiyaç duyulan zihinsel kapasiteyi anlatmaktadır. Kişisel özelliklere işaret eden bu kaynakların durumu da genel olarak eğitim ve gelir düzeyi ile yakından bağlantılıdır (s. 271).

Çeşitli araştırmalar, yaşın seçimlere katılım ve oy verme üzerinde önemli bir etkiye sahip olduğunu göstermiş olup diğer etkenler benzer olsa bile gençlerin daha az oy kullanma eğiliminde oldukları ifade edilmektedir (Dalton, 2002; Oppenhuis, 1995). İleri kapitalist toplumlarda görülen en dikkat çekici eğilim, öğrencilerin siyasal yaşama katılımlarının giderek azalması şeklinde karşımıza çıkmaktadır. Touraine (2002) bugün genel olarak dünyada, siyasal yaşama karşı bir ilgisizlik duyulduğuna dikkat çekerek toplumsallaşmadan, toplumsal bütünleşmeden, siyasal yaşama katılımdan söz etmenin artık geçmişte gözlemlediğimiz deneyimlerle bağdaşmayan bir iş haline geldiğini, 1980 'lerden itibaren oy verme oranlarının giderek düştüğünü ifade etmektedir (s. 188). Jean M. Twenge (2009) de 1,3 milyon üniversiteli hakkındaki bilgelere dayanan 12 araştırmanın sonuçlarını yorumladığı Ben Nesli adlı kitabında ABD’de görülen benzer bir eğilimden söz etmektedir. Aynı üniversitede farklı tarihlerde yapılan araştırma sonuçlarına göre 1966'da öğrencilerin \%60'1 siyasi olaylarla ilgilenmenin önemli bir yaşam hedefi olduğunu belirtirken, 2000 yılına gelindiğinde öğrencilerin sadece \%10’u bu fikre katıldığını söylemektedir (s. 198). Gençlerin seçimlere katılımının giderek azaldığını belirten David Mindich (2005) de ABD, Kanada, Batı Avrupa, Japonya ve Latin Amerika'da durumun benzer olduğuna dikkati çekmektedir (s. 22). Edward Fieldhouse, Mark Tranmer ve Andrew Russel (2007) tarafından yapılan bir başka araştırma, Avrupa'da gençlerin seçimlere katılma oranının yaşlılara oranla daha düşük olduğunu göstermektedir (s. 798). André Blais, Elisabeth Gidengil ve Neil Nevitte (2004) genç nesillerin oy vermeye daha az eğilimli olmalarını, siyasete daha az ilgili olmalarına bağlamakta ve oy vermeyi sadece bir hak değil, ahlaki bir sorumluluk olarak da gören eski kuşaklar gibi düşünmediklerini ifade etmektedirler (s. 221). Bu anlamda seçimlere katılımdaki düşüş aslında daha genel bir sosyal ve kültürel değişimin bir parçası olarak okunabilir. Nitekim günümüzün gençliği haber izlemek ya da gazete okumak için anne babalarından çok daha az vakit harcamakta ve yaşadıkları toplumdaki politik olaylar hakkında bilgi edinme ya da kamusal meseleleri tartışma konusunda daha isteksiz davranmaktadır (Mindich, 2005). Genel olarak düşük düzeyde siyasal ilgi ve bilgiye sahip olan gençler, herhangi bir şeyi değiştirme gücüne sahip olduklarına inanmadıkları gibi politik sisteme ve politikacilara güvenmediklerini ifade etmektedirler (Fer, 2015, s. 2). Siyaset hakkında daha az okuyan, siyasal haberlere daha az ilgi duyan gençlerin siyaset hakkındaki bilgilerinin de sinırlı olduğunu belirten Delli Carpine ve Keeter (1996) bu durumu "zayıf vatandaşlık" olarak adlandırmaktadırlar.

Mevcut durumu farklı okuyanlar ise gençlerin politika ile hala ilgilendikleri ancak bunun için geleneksel yolları takip etmediklerini ileri sürmektedirler (Della Porta ve Mosca 2005; Di Maggio, Hargittai, Neuman ve Robinson, 2001; Norris, 2002). Siyasi partilere üye olmayan gençler dijital 
platformlardaki toplumsal olaylara dair kampanyalara gönüllü olarak katılmakta, politik gündemi daha çok internet ve sosyal ağlar üzerinden takip etmektedirler (Bode ve Dalrymple, 2014). Geleneksel siyasete mesafeli olan gençler, aktif oldukları çevrimiçi ağlarda güncel politik konularla ilgili mesajlara maruz kalmaktadırlar (Baumgartner ve Morris, 2010, s. 25). Seçmenleri, siyasi partilere üye olan ve mevcut yollara öncelik veren gelenekseller, mevcut siyasal yapıya muhalif olup yeni politik katılım biçimlerine önem veren dönüşümcüler, her iki katılım yolunu da destekleyen yüksek ilgililer ve her iki katılım biçimine de fazla ilgi göstermeyen düşük ilgililer olmak üzere dört grupta toplayan Davide Calenda ve Albert Meijer (2009) gençler arasında teknoloji aracılı dijital platformları öne çıaran dönüşümcü siyasal katılım biçiminin daha yaygın olduğunu ifade etmektedirler (s. 884). Darren G. Lilleker ve Karolina Koc-Michalskảnın (2017) araştırmasına göre de eğitim, siyasal katılımda güçlü bir teşvik edici öğe olarak karşımıza çıkmakta olup özellikle üniversiteli gençler, dijital platformlardaki siyasal aktivitelere daha yoğun ilgi göstermektedir. Sidney Kraus ve Dennis Davis (1978) ile Brian McNair'in (1995) çalışmaları da medyanın gençlerin siyasal tutumlarını şekillendirmede önemli bir rol oynadığı sonucuna ulaşmıştır. Kenski ve Stroud (2006), Vitak ve ark. (2011), Homero Gil de Zuniga, Nakwon Jung ve Sebastián Valenzuela (2012), Dharma Tintri Ediraras, Dewi A. Rahayu, Ary Natalina ve Winda Widya (2013), Kim Strandberg (2013) ile Weiwu Zhang, Trent Seltzer ve Shannon L. Bichard (2013) tarafından yapılan çalışmalar, sosyal medyanın gençlerin siyasal katılımını etkilediğini göstermektedirler. Kaye D. Sweetser ve Ruthann Weaver Lariscy (2008) adaylar için özellikle genç seçmenleri kazanma ve onlarla iki yönlü bir iletişim kurma konusunda Facebook’un önemli bir mecra olduğunu belirtmektedirler. Vitak ve arkadaşlarının (2011) çalışması, Facebook'un politik amaçlar için kullanım yoğunluğu ve öğrencilerin siyasal katılım düzeyleri arasında pozitif bir ilişki olduğunu öne sürmektedir. Bununla birlikte Matthew James Kushin ve Masahiro Yamamoto (2010) tarafından yapılan çalışmada ise sosyal medyanın genç yetişkinlerin siyasal katılım düzeyine etkisinin oldukça sınırlı olduğu sonucuna ulaşılmıştır.

Lynda L. Kaid, Mitchell S. McKinney ve John C. Tedesco (2007) gençlerin siyasal katılım eksikliklerini büyük oranda siyasal bilgi eksikliklerine bağladıklarını bulmuşlardır. Shakuntala Banaij ve David Buckingham (2010) gençlerin, geleneksel medyada bulamadıkları siyasal bilgiye ulaşmak için internet ve sosyal medyayı kullandıklarını ortaya koymuşlardır. Sonia Livingstone ve Moira Bovill'in (2000) çalışmasına göre ise gençler için haber alma ve takip etmede öncelikli mecra, televizyon olup bunu internet ve gazete takip etmektedir. Şükrü Balcı ve Tuba Bor’un (2015) üniversite öğrencilerini kapsayan araştırmalarında ise siyasal bilgilenme araçları arasında gazete ilk sırada gelirken bunu televizyon ve internet izlemektedir. Diana Owen ve Jack Dennis (1992) çalışmasına göre kadınlar ve erkekler politik bilgi için farklı medyalara başvurmakta, erkekler daha çok gazeteyi kadınlar ise televizyonu tercih etmektedirler.

\section{Yöntem}

$\mathrm{Bu}$ çalışma eğitim düzeyi aynı olan ve gelecekte siyasal iletişim alanında çalışma ihtimali yüksek olan iletişim fakültesi ögrencilerinin oy verme ve siyasal gündem takibi üzerinde mecranın etkisini anlamaya yöneliktir. Çalışma, "İletişim fakültesi öğrencileri siyasal bilgi alma ve siyasal katılım için 
hangi araçları kullanıyorlar?", "Seçim kampanyasında kullanılan iletişim mecralarının etkinliğini nasıl değerlendiriyorlar?" ve "Referanduma dair haber ve paylaşımları referandum öncesi ve sonrasında hangi sıklıkta takip ettiler?" sorularını cevaplamayı hedeflemektedir.

İletişim fakültesi öğrencilerinin seçim kampanyalarında iletişim mecralarının etkileri ve sosyal medya paylaşımlarının oy verme davranışı ve kararı üzerindeki etkisini 16 Nisan 2017 tarihindeki anayasa değişikliği referandumu kampanyası örneğinde anlamayı amaçlayan bu araştırma kapsamında, 3-7 Nisan 2017 ve 17-21 Nisan 2017 tarihleri arasında Sakarya Üniversitesi ile Niğde Ömer Halisdemir Üniversitesi iletişim fakülteleri öğrencilerine anket uygulanmıştır.

Önceki araştırmalar sadece seçim sonrasında yapıldığg için kampanya süresince bir değişim yaşanıp yaşanmadığının ortaya konulabilmesi açısından eksik kalmaktadırlar. Bu çalışma kapsamında anketler, siyasal haberlerin en yüksek noktaya ulaştığı referandumdan önceki bir hafta ile referandumun hemen arkasından gerçekleştirilmiştir. Böylece kampanya süresince takip edilen haberlerin öğrencilerin oy verme kararı ile oyun içeriği üzerindeki etkisi anlaşılmaya çalışılmıştır.

Araştırmanın amaçları doğrultusunda yalnızca iletişim fakültesi öğrencileri dikkate alınmıştır. Yükseköğretim Kurulu (YÖK) verilerine göre ülkemizde 50'den fazla (KKTC dahil) iletişim fakültesi bulunmaktadır, ancak bu fakültelerin bir kısmında bazı bölümler henüz açılmamış ya da eğitim-öğretime başlanmamıştır. YÖK tarafından açıklanan 2016-2017 Yükseköğrenim İstatistiklerine göre aktif olarak 48 üniversitede 47 iletişim ve 1 iletişim bilimleri fakültesinde yaklaşık 50 bin öğrenci eğitim görmektedir. Araştırmanın evreni Türkiye’deki iletişim fakültelerinin öğrencileridir. Tüm iletişim fakültelerine ulaşmak zaman, maliyet ve emek açısından mümkün olamayacağı için iki üniversitenin iletişim fakülteleri araştırmacıların erişim kolaylığı sebebiyle tercih edilmiştir. Veriler anket yöntemi ile toplanmıştır. Anket formunun referandum öncesi bölümünü 409 öğrenci, referandum sonrası bölümünü 402 öğrenci cevaplamış olup sonuçlar değerlendirilirken önceki bölüme katılmayan 7 öğrenci ile seçme yaşından küçük oldukları için oy kullanamayan 6 öğrenci değerlendirmeye dahil edilmemiştir. Toplam 396 öğrenciden toplanan verilerin değerlendirilmesinde SPSS 19.0 istatistik programındaki frekans analizi kullanılmıştır. Yahşi Yazıcıoğlu ve Samiye Erdoğan (2004) tarafından önerilen 0,95 güvenirlik ve 0,05 örneklem hatası ile temsil edilebilecek evren büyüklüklerine dair Tablo 1'e göre 396 kişilik bir örneklemin 1.000.000 kişilik bir evreni temsil edebileceği görülmektedir ve dolayısıyla araştırmanın örneklem sayısının yeterli olduğu söylenebilir (s. 49).

Tablo I. Örneklem Sayıları

\begin{tabular}{|l|l|l|l|l|l|l|l|l|l|l|l|}
\hline Evren Büyüklüğ̈̈ & 100 & 500 & 750 & 1000 & 2500 & 5000 & 10000 & 25000 & 50000 & 100000 & 1000000 \\
\hline Örneklem Sayısı & 80 & 217 & 254 & 278 & 333 & 357 & 370 & 378 & 381 & 383 & 384 \\
\hline
\end{tabular}

Araştırma kapsamındaki 48 fakültenin müfredatları genel olarak incelenmiş ve hemen hemen tüm üniversitelerde öğrencilerin Siyaset Bilimi, Siyasal Düşünceler Tarihi, Siyasal İletişim, Siyasal Davranış, Siyasal Reklam, Kamuoyu Araştırmaları, İmaj Yönetimi gibi siyaset ile iletişimin kesişimindeki çeşitli dersleri aldıkları görülmüştür. Bu bakımdan iletişim fakültesi öğrencilerinin 
siyasal iletişimde kullanılan kitle iletişim araçlarının etkinlik ve verimliliğine dair temel düzeyde bilgi sahibi oldukları ifade edilebilir. Gelecekte siyasal iletişim alanında çalışma ihtimali yüksek olan iletişim fakültesi öğrencilerinin başta çağın yükselen medyası internet ve sosyal medya olmak üzere iletişim mecraları hakkında da fikir sahibi olmaları beklenecektir.

Araştırmada iletişim araçları ve sosyal medyanın etkinliğinin ortaya konulabilmesi için referandum öncesinde ve sonrasında aynı öğrencilere anketler kâğıt üzerinde dağıtılarak uygulanmıştır. Anket formları sahaya uygulanmadan önce 10 kişilik bir örneklem grubu üzerinde ön test gerçekleştirilmiş, anlaşılırlık ve yapılacak analizlere uygunluk düzeyi saptanarak gerekli düzenlemelere gidilmiş, anket formlarına nihai şekli verilmiştir. Nihai anket formları toplam 19 sorudan oluşmakta olup yaş ve cinsiyetle ilgili demografik bilgileri müteakip "her zaman" ile "hiçbir zaman" arasında değişen 5’li Likert ölçeğine dayanan sosyal medya sitelerinin takibine dair sorular bulunmaktadır. Anket formunda öğrencilerden siyasal seçim kampanyalarında sık kullanılan iletişim mecralarının etkinliğini “çok etkili” ile “etkisiz” arasında değişen 5’li Likert ölçeğinde değerlendirmeleri istenmiştir. Referanduma dair haberleri ve partilerin sosyal medya paylaşımlarını ne sıklıkta takip ettikleri referandum öncesi ve sonrasında ayrı ayrı sorulmuştur. Öğrencilere ayrıca referandum öncesi bölümde referandumda oy kullanmayı düşünüp düşünmedikleri, düşünüyorlarsa karar verip vermedikleri sorulmuştur. Referandum sonrası bölümde ise oy kullanıp kullanmadıkları, seçim sürecinde takip ettikleri haberlerin kararlarında etkisi olup olmadığı sorulmuş ve ayrıca referandum öncesindeki kararlarında bir değişiklik olduysa bu değişimde okudukları ya da izledikleri haberlerin etkisini değerlendirmeleri istenmiştir.

\section{Bulgular}

\section{Demografik Özellikler}

Araştırmaya katılan öğrencilerin demografik özelliklerine bakıldığında yaklaşık \% 55 ’inin kadın ve $\% 45^{\prime}$ inin ise erkek olduğu, öğrencilerin yaklaşı \%46'lık bölümünün 18-20 yaş aralığında yer aldığı görülmektedir. \%37,1 oranında 20-22 yaş arasında katılımcı bulunurken \%10 oranında da 2225 yaş arası katılımcı çalışmaya dâhil olmuştur. Öğrencilerin \%5,1'lik kısmı ise 25 yaşından büyüktür.

Tablo 2. Demografik Özellikler

\begin{tabular}{|l|l|l|l|}
\cline { 3 - 4 } \multicolumn{2}{c|}{} & Frekans & Yüzde \\
\hline \multirow{4}{*}{ CINSİYET } & Kadın & 217 & $\% 54,8$ \\
\cline { 2 - 4 } & Erkek & 179 & $\% 45,2$ \\
\cline { 2 - 4 } & Toplam & 396 & $\% 100$ \\
\hline \multirow{5}{*}{ YAŞ } & 18 'den küçük & 6 & $\% 1,5$ \\
\cline { 2 - 4 } & $18-20$ arası & 183 & $\% 46,2$ \\
\cline { 2 - 4 } & $20-22$ arası & 147 & $\% 37,1$ \\
\cline { 2 - 4 } & $22-25$ arası & 40 & $\% 10,1$ \\
\cline { 2 - 4 } & 25 'ten büyük & 20 & $\% 5,1$ \\
\cline { 2 - 4 } & Toplam & 396 & $\mathbf{1 0 0}$ \\
\hline
\end{tabular}




\section{İletişim Mecralarının Etkinliği}

Seçim kampanyalarında sık kullanılan iletişim mecralarının etkililiğine dair sonuçlar incelediğinde, öğrencilerin \%37,9'u internet sitelerini “çok" etkili, \%28,5'i “oldukça” etkili ve \%24,2'si de "etkili" bulduğunu ifade etmektedir. Bu oranlar sosyal medya platformları içinse sırasıyla \%57,8, \%23,5 ve \%13,1'dir. Öğrencilerin \%47,5'i televizyonun “çok” etkili, \%27,5'i “oldukça” etkili ve \%18,2'si ise "etkili” olduğunu düşünürken gazete, radyo ve açıkhava mecraları için bu oranların daha düşük olduğu göze çarpmaktadır. Seçim kampanyalarında yüz yüze iletişimin etkisine dair oranlar ise daha yüksektir. Öğrencilerin \%44,4'ü yüz yüze iletişimi “çok” etkili, \%16,4'ü "oldukça” etkili ve $\% 26,8$ 'i ise "etkili” bir mecra olarak değerlendirmektedir. Öğrencilerin "çok" ve "oldukça” etkili bulduğu mecraların toplam oranlarına bakıldığında ilk sırada \%81,3 ile sosyal medyanın geldiği görülmektedir. Bunu \%75 ile televizyon, $\% 66,4$ ile internet siteleri, $\% 60,8$ ile yüz yüze iletişim, \%33,8 ile açıhava izlemektedir. Gazete ve radyo \%29,1 ve \%13,9 oranları ile son sıralarda yer almaktadır.

Tablo 3. İletişim Mecralarının Etkinliği

\begin{tabular}{|l|l|l|l|l|l|l|l|l|l|l|}
\cline { 2 - 14 } \multicolumn{1}{c|}{} & \multicolumn{2}{l|}{ Çok etkili } & \multicolumn{2}{l|}{ Oldukça etkili } & \multicolumn{2}{l|}{ Etkili } & \multicolumn{2}{l|}{ Az etkili } & \multicolumn{2}{l|}{ Etkisiz } \\
\cline { 2 - 14 } \multicolumn{1}{c|}{} & $\mathrm{F}$ & $\mathrm{Y}$ & $\mathrm{F}$ & $\mathrm{Y}$ & $\mathrm{F}$ & $\mathrm{Y}$ & $\mathrm{F}$ & $\mathrm{Y}$ & $\mathrm{F}$ & Y \\
\hline İnternet siteleri & 150 & $\% 37,9$ & 113 & $\% 28,5$ & 96 & $\% 24,2$ & 23 & $\% 5,8$ & 14 & $\% 3,5$ \\
\hline Sosyal medya & 229 & $\% 57,8$ & 93 & $\% 23,5$ & 52 & $\% 13,1$ & 5 & $\% 1,3$ & 17 & $\% 4,3$ \\
\hline Televizyon & 188 & $\% 47,5$ & 109 & $\% 27,5$ & 72 & $\% 18,2$ & 11 & $\% 2,8$ & 16 & $\% 4,0$ \\
\hline Gazete & 30 & $\% 7,6$ & 85 & $\% 21,5$ & 173 & $\% 43,7$ & 85 & $\% 21,5$ & 23 & $\% 5,8$ \\
\hline Radyo & 20 & $\% 5,1$ & 35 & $\% 8,8$ & 70 & $\% 17,7$ & 198 & $\% 50,0$ & 73 & $\% 18,4$ \\
\hline Açıkhava & 59 & $\% 14,9$ & 75 & $\% 18,9$ & 129 & $\% 32,6$ & 83 & $\% 21,0$ & 50 & $\% 12,6$ \\
\hline Yüz yüze iletişim & 176 & $\% 44,4$ & 65 & $\% 16,4$ & 106 & $\% 26,8$ & 32 & $\% 8,1$ & 17 & $\% 4,3$ \\
\hline
\end{tabular}

\section{Gündem Takibi Mecraları}

Öğrencilerin çok büyük bir kısmı olan yaklaşık \%74’ü ülke gündemine dair haberleri ve gelişmeleri internetten (gazetelerin web siteleri ve haber siteleri) takip ettiğini belirtmiştir. Gündem takibinde televizyon \%21 oranıyla ikinci sırada gelmektedir. İnternet, gündem takibinde ilk sıradaki mecra olmakla birlikte referandumun tarihini öğrencilerin neredeyse yarısı $(\% 49,2)$ televizyondan öğrendiğini ifade etmiştir. Televizyonu \%39 oranılla internet ve \%10,9 oranı ile aile/ arkadaş çevresi takip etmektedir. 
Tablo 4. Gündem Takibi ve Referandum Tarihi

\begin{tabular}{|l|l|l|l|l|}
\cline { 2 - 5 } \multicolumn{1}{c|}{} & \multicolumn{2}{c|}{ Gündem Takibi } & \multicolumn{2}{l|}{ Referandum Tarihi } \\
\cline { 2 - 5 } \multicolumn{1}{c|}{} & Frekans & Yüzde & Frekans & Yüzde \\
\hline İnternet & 292 & $\% 73,7$ & 155 & $\% 39,1$ \\
\hline Televizyon & 83 & $\% 21,0$ & 195 & $\% 49,2$ \\
\hline Gazete & 4 & $\% 1,0$ & 2 & $\% 0,5$ \\
\hline Radyo & 3 & $\% 0,8$ & 1 & $\% 0,3$ \\
\hline Aile/arkadaş çevresi & 14 & $\% 3,5$ & 43 & $\% 10,9$ \\
\hline Toplam & $\mathbf{3 9 6}$ & $\% \mathbf{1 0 0}$ & $\mathbf{3 9 6}$ & $\% \mathbf{1 0 0}$ \\
\hline
\end{tabular}

Sosyal medya siteleri takibine dair Tablo 5 'te görüldüğü üzere, Instagram öğrencilerin $\% 63,4$ 'ü (251 kişi) tarafından, Youtube \%39,6’sı (157 kişi) tarafından, Twitter \%29,3’i (116 kişi) ve Facebook da \%22,7’si (91 kişi) tarafından “her zaman” takip edilmektedir. Öğrencilerin “sık sık” takip ettiklerini belirttikleri sosyal medya siteleri ise sirasiyla Youtube (\%38,1), Facebook $(\% 23)$, Twitter $(\% 22,2)$ ve Instagram $(\% 17,9)$ olarak karşımıza çıkmaktadır. Sosyal medya sitelerinin "her zaman" ve "sık sık" kullanım oranlarının toplamları dikkate alındığında Instagram \%81,3 oranı ile ilk sırada yer alırken bunu \%77,7 oranı ile Youtube, \%51,5 oranı ile Twitter ve \%45,7 oranı ile Facebook takip etmektedir. We Are Social ve Hootsuite tarafından yayınlanan ve internet ve sosyal medya kullanım istatistiklerini içeren Ocak 2017 tarihli Digital in 2017 Global Overview raporuna göre aktif kullanıcı sayısı bakımından dünya genelinde Facebook ilk sırada, Youtube ikinci sırada, Instagram üçüncü sırada ve Twitter dördüncü sırada gelmektedir. Ülke genelinde en aktif kullanılan sosyal medya platformları sıralamasına göre ise Türkiye’de Youtube ilk sırada gelirken, bunu Facebook, Instagram ve Twitter takip etmektedir. Öğrencilerin sıralamasında Instagram ilk sırada gelmektedir.

Tablo 5. Sosyal Medya Siteleri Takibi

\begin{tabular}{|l|l|l|l|l|l|l|l|l|l|l|}
\cline { 2 - 12 } \multicolumn{1}{c|}{} & \multicolumn{3}{c}{ Her zaman } & \multicolumn{2}{l|}{ Sık sık } & \multicolumn{2}{l|}{ Bazen } & \multicolumn{2}{l|}{ Çok azbir zaman } \\
\cline { 2 - 13 } \multicolumn{1}{c|}{} & $\mathrm{F}$ & $\mathrm{Y}$ & $\mathrm{F}$ & $\mathrm{Y}$ & $\mathrm{F}$ & $\mathrm{Y}$ & $\mathrm{F}$ & $\mathrm{Y}$ & $\mathrm{F}$ & Y \\
\hline Youtube & 157 & $\% 39,6$ & 151 & $\% 38,1$ & 78 & $\% 19,7$ & 3 & $\% 0,8$ & 7 & $\% 1,8$ \\
\hline Facebook & 90 & $\% 22,7$ & 91 & $\% 23,0$ & 88 & $\% 22,2$ & 72 & $\% 18,2$ & 55 & $\% 13,9$ \\
\hline Instagram & 251 & $\% 63,4$ & 71 & $\% 17,9$ & 37 & $\% 9,3$ & 15 & $\% 3,8$ & 22 & $\% 5,6$ \\
\hline Twitter & 116 & $\% 29,3$ & 88 & $\% 22,2$ & 82 & $\% 20,7$ & 22 & $\% 5,6$ & 88 & $\% 22,2$ \\
\hline Scorp & 6 & $\% 1,5$ & 10 & $\% 2,5$ & 27 & $\% 6,8$ & 90 & $\% 22,7$ & 263 & $\% 66,4$ \\
\hline Blogger & 22 & $\% 5,6$ & 21 & $\% 5,3$ & 73 & $\% 18,4$ & 65 & $\% 16,4$ & 215 & $\% 54,3$ \\
\hline
\end{tabular}

Öğrencilerin ülke gündemine dair haberler ile siyasal gelişmeleri en fazla hangi sosyal medya sitesinden öğrendiklerine dair Tablo 6’da görüleceği üzere Facebook yaklaşık \%49 oranı ile birinci sıradadır. Twitter ise \%31,4 oranı ile ikinci sırada gelmektedir. Bu durum dünya genelindeki sonuçlarla benzerlik göstermektedir. Zira sosyal medyanın politik katılıma etkilerine yönelik araştırmalar (Di Gennaro ve Dutton, 2006; Calenda ve Meijer, 2009; Kushin ve Yamamoto, 2010; Gerbaudo, 2012; Spada, Mellon, Peixoto ve Sjoberg, 2016) da daha çok Facebook ile Twitter üzerinde yoğunlaşmaktadır. Bunda Facebook ve Twitter’ın kişiler arasında anlık mail gönderimi ile grup kurma ya da var olan gruplara katılmaya izin 
veren yapısının etkili olduğu söylenebilir. Siyasal partilerin de internet üzerinden seçim kampanyalarında Facebook ve Twitter’a öncelik verdikleri söylenebilir.

Tablo 6. Gündem Takibinde Sosyal Medya Siteleri

\begin{tabular}{|l|l|l|}
\cline { 2 - 3 } \multicolumn{1}{c|}{} & Frekans & Yüzde \\
\hline Facebook & 194 & $\% 48,9$ \\
\hline Twitter & 124 & $\% 31,4$ \\
\hline Youtube & 54 & $\% 13,6$ \\
\hline Instagram & 16 & $\% 4,1$ \\
\hline Blogger & 6 & $\% 1,5$ \\
\hline Scorp & 2 & $\% 0,5$ \\
\hline Toplam & $\mathbf{3 9 6}$ & $\mathbf{1 0 0}$ \\
\hline
\end{tabular}

Öğrencilerin referanduma dair haberleri, tartışma programlarını ve sosyal medya paylaşımlarını takip sıklıklarına bakıldığında (Tablo 7) referandum öncesinde ilgili haberleri "hemen her gün takip ediyorum" diye cevap verenlerin oran $1 \% 34,3$, "s1k s1k takip ediyorum" diyenlerin oran $1 \% 28,5$ ve "bazen takip ediyorum" diye cevap verenlerin oranı ise \%26,8'dir. Referandum öncesindeki sosyal medya paylaşımlarını takip oranları ise sırasıyla \%14,4, \%33,3 ve \%40,2 şeklindedir. Hiç takip etmediğini ifade edenlerin oranları ise haberler için $\% 1,5$ ve sosyal medya paylaşımları için de \%5,3’te kalmıştır. Oranlar referandum öncesinde referandumla ilgili haber ve sosyal medya paylaşımlarının öğrenciler tarafından büyük oranda okunduğunu ya da izlendiğini göstermektedir. Referandum sonrasındaki haberler ve sosyal medya paylaşımlarının takibine dair oranlara bakıldığında ise "hiç takip etmediğini" söyleyenlerin \%5,1 ile \%6,1 olduğu görülmektedir. "Fazla takip etmediğini" söyleyenlerin oranlarında fazla bir değişiklik görülmezken "hemen her gün" takip ettiğini söyleyenlerin oranı haberler için \%14,4'e ve sosyal medya paylaşımları içinse \%23'e düşmüştür. Buna karşın "sık sık" takip ettiğini söyleyenlerin oranlarında yükselme (haberler için \%33,3 ve sosyal medya paylaşımları için \%44,7) göze çarpmaktadır.

Tablo 7. Haber ve Sosyal Medya Takibi

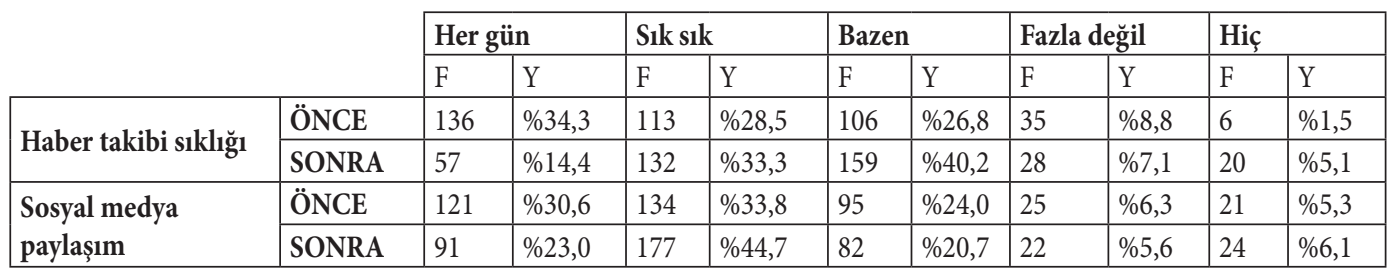

\section{Oy Vermede Haberlerin Etkisi}

Referandum öncesinde katılımcıların yaklaşık \%80'ine tekabül eden 316 öğrenci oy kullanmayı düşündügünü söylemiş ve katılımcıların \%77’sine tekabül eden 305 öğrenci referandumda oy kullandığını belirtmiştir. Referandum öncesinde oy kullanmayı düşünmediğini ifade eden 31 
öğrenci ve henüz karar vermediğini söyleyen 49 öğrenci vardır. Referandum sonrasında ise 91 öğrenci oy kullanmadığını ifade etmiştir. Kampanya öncesinde henüz karar vermemiş olan ve kullanmayı düşünmediğini söyleyen öğrencilerin toplamı 80 kişidir ve bu durumda 11 öğrencinin oy kullanmadığı sonucuna varılabilir.

Anketin referandum öncesi kısmında öğrencilerin \%81,6’s1 (323 öğrenci) vereceği oyun içeriğine karar verdiğini ifade ederken henüz karar vermemiş olanların oranı \%18,4’te (73 öğrenci) kalmıştır. Bu durumda oy kullanmayı düşündüğünü söyleyen öğrencilerin (316 kişi) sadece 7’sinin vereceği oyun içeriğine referandum öncesinde karar vermediği sonucuna ulaşılabilir.

Tablo 8. Oy Kullanma

\begin{tabular}{|l|l|l|l|l|}
\cline { 2 - 5 } \multicolumn{1}{c|}{} & \multicolumn{2}{c|}{ ÖNCE } & \multicolumn{2}{l|}{ SONRA } \\
\cline { 2 - 5 } \multicolumn{1}{c|}{} & F & Y & F & Y \\
\hline Evet, düşünüyorum / kullandım & 316 & $\% 79,8$ & 305 & $\% 77,0$ \\
\hline Hayır, düşünmüyorum / kullanmadım & 31 & $\% 7,8$ & 91 & $\% 23,0$ \\
\hline Henüz karar vermedim & 49 & $\% 12,4$ & X & X \\
\hline Toplam & $\mathbf{3 9 6}$ & $\% 100$ & $\mathbf{3 9 6}$ & $\% 100$ \\
\hline
\end{tabular}

Anketin referandum sonrası kısmında referandumda oy kullandığını belirten öğrencilerden seçim kampanyası süresince izlediği/okuduğu haberlerin kullandığı oy üzerindeki etkisini değerlendirmeleri de istenmiştir. Bu sorunun cevabına dair Tablo 9'da da görüldüğü üzere, öğrencilerin \%30,8’i haberleri "etkisiz" olarak değerlendirmiștir. Haberlerin "az etkili” olduğu söyleyen öğrencilerin oranı ise \%21,6’dır. Buna karşın öğrencilerin \%24,5’i haberleri oy kararları üzerinde "etkili” bulurken öğrencilerin \%14,4’ü haberlerin “oldukça” etkili ve \%8,7’si de “çok" etkili olduğunu ifade etmiştir.

Tablo 9. Haberlerin Karara Etkisi

\begin{tabular}{|l|l|l|l|l|l|l|l|l|l|l|l|l|l|}
\cline { 2 - 12 } \multicolumn{1}{c|}{} & \multicolumn{2}{c|}{ Çok etkili } & \multicolumn{3}{l|}{ Oldukça etkili } & Etkili & \multicolumn{3}{l|}{ Az etkili } & \multicolumn{2}{l|}{ Etkisiz } & \multicolumn{2}{l|}{ Toplam } \\
\cline { 2 - 13 } \multicolumn{1}{c|}{} & F & Y & F & Y & F & Y & F & Y & F & Y & F & Y \\
\hline Haber Etkisi & 26 & $\% 8,7$ & 44 & $\% 14,4$ & 75 & $\% 24,5$ & 66 & $\% 21,6$ & 94 & $\% 30,8$ & $\mathbf{3 0 5}$ & $\% 100$ \\
\hline
\end{tabular}

Anketin referandum sonrası kısmında seçim kampanya süreci öncesinde verdiği kararda değişiklik olduğunu söyleyenlerin oranı \%26,3 (104 öğrenci) iken bir değişiklik olmadığını belirtenler ise \%73,7 (292 öğrenci) oranı ile yaklaşık üç kat fazladır. Öğrencilerin büyük oranda referandum öncesinde karar verdikleri anlaşılmaktadır. Referandum öncesindeki kararında değişiklik olduğunu belirten öğrencilerin, bu değişiklikte seçim kampanyası süresince izlediği/okuduğu haberlerin etkisine dair değerlendirmelerine bakıldığında (Tablo 10) ise öğrencilerin \%71,2'i “etkili” sayılabileceğini, \%16,4'ü "oldukça" ve yaklaşık \%2'si de "çok" etkili olduğunu ifade etmektedir. Bir başka deyişle kararını değiştiren öğrenciler arasında haberleri bu değişimde etkili bulanların oranı toplamda \%90'dan fazladır. Buradan hareketle kampanya süresince kararını değiştiren öğrencilerin oranının (\%26) yüksek olmamakla beraber kararını değiştiren öğrenciler arasında haberleri bu değişimde etkili bulanların oranının oldukça yüksek olduğu söylenebilir. 
Tablo I0. Haberlerin Değişikliğe Etkisi

\begin{tabular}{|l|l|l|l|l|l|l|l|l|l|l|}
\cline { 2 - 13 } & \multicolumn{2}{c|}{ Çok etkili } & \multicolumn{2}{l|}{$\begin{array}{l}\text { Oldukça } \\
\text { etkili }\end{array}$} & \multicolumn{2}{l|}{ Etkili sayılabilir } & \multicolumn{2}{l|}{ Az etkili } & \multicolumn{2}{l|}{ Toplam } \\
\cline { 2 - 13 } & F & Y & F & Y & F & Y & F & Y & F & Y \\
\hline Haberlerin Değișikliğe Etkisi & 2 & $\% 1,9$ & 17 & $\% 16,4$ & 75 & $\% 72,1$ & 10 & $\% 9,6$ & 104 & $\% 100$ \\
\hline
\end{tabular}

\section{Sonuç ve Yorum}

Siyasal katılım, seçimlerden çok daha geniş ve çok faktörlü bir olgu olmakla birlikte oy vermek siyasal katılımın önemli bir göstergesidir. Günümüzde siyasal katılımı kitle iletişim araçlarından bağımsız düşünmek neredeyse olanaksız hale gelmiştir. Kitle iletişim araçlarının toplumsal rolünün zamanla daha iyi anlaşılması ve özellikle siyasal süreçlerde daha etkin ve verimli olarak kullanılması, internet ve sosyal medyanın da sürece dahil olmasıyla beraber gözle görülür bir ivme kazanmıştır.

Ülkemizde 16 Nisan 2017 tarihinde gerçekleştirilen Anayasa Değişikliği Referandumu sürecinde, iletişim mecralarının iletişim fakültesi öğrencilerinin oy verme davranışına etkilerini incelemeyi hedefleyen bu çalışma kapsamında uygulanan ankette öğrencilere; gündem takibi, referandumla ilgili haber takibi, iletişim mecraları takibi, oy kullanma, haberlerin kararlara etkisi gibi başlıklar altında sorular yöneltilerek, iletişim mecraları kullanım alışkanlıklarının referandumda oy verme davranışı üzerindeki etkisine bakılmıştır. Anket çalışmasına katılan öğrencilerin yaş ortalaması 18-25’tir. Bununla birlikte ankete yoğun katılımın 18-22 yaş aralığında olduğu görülmektedir. Öğrencilerin siyasal iletişim mecralarının etkinliğine dair değerlendirmelerine bakıldığında, "çok" ve "oldukça" etkili buldukları mecra sıralamasında sosyal medya ilk sırada gelmektedir. Toplamda televizyon ikinci sırada, internet üçüncü sırada bulunmakta ve radyo da son sırada gelmektedir. İnternet, yüz yüze iletişim ve kitle iletişim araçları gibi mevcut platformlara önemli ve yeni bir araç olarak katkıda bulunarak bu alanlarla çeşitli şekillerde etkileşime girmektedir. Siyasal katılım için yeni fırsatların bu kombinasyonu yeni politik aktiviteleri de içermektedir. İnternetin artık siyasal iletişim de dahil olmak üzere hemen her alanda geleneksel mecraların önüne geçtiğini ileri sürmek yanlış olmayacaktır. Bununla birlikte bu sonuçlarda araştırmanın internet ve sosyal medya kullanım oranlarının diğer yaş gruplarına göre yüksek olduğu gençler üzerinde yapılmış olmasının etkili olduğu da ifade edilebilir. Zira 2016 yılı TÜİK Hanehalkı Bilişim Teknolojileri Kullanım Araştırması̉na göre Türkiyede 1624 yaş arasındaki kişilerin internet kullanım oranı \%70, 25-35 yaş arasındakilerin \%63, 35-44 yaş arasındakilerin \%51'dir. Yaş ilerledikçe kullanım oranı düşmektedir.

Öğrencilerin siyasal gündemi takip mecralarına bakıldığında da internet yaklaşık \%74 oranıyla ilk sırada gelmektedir. Bunu \%21 oranıyla televizyon takip ederken radyo ve gazete en az başvurulan araçlar olarak karşımıza çıkmaktadır. Bu sonuç, gençlerin haber takibinde kullandıkları öncelikli mecra olarak televizyonu tercih ettiğini gösteren Livingstone ve Bovill'in (2000) çalışmasından da, daha yeni tarihli olmakla birlikte en fazla tercih edilen mecra olarak gazeteyi işaret eden Balcı ve Bor'un (2015) çalışmasından da farklılık göstermektedir. Bununla birlikte öğrencilerin siyasal iletişimde en etkili buldukları mecranın sosyal medya olduğu düşünüldüğünde bu sonuç, iletişim mecralarının etkinliğine dair cevapları ile uyumludur. Ancak öğrencilerin siyasal haber takibinde 
sosyal medyayı daha etkili buldukları için mi tercih ettikleri yoksa daha yoğun kullandıkları için mi daha etkili bulduklarını anlamak için farklı çalışmalara ihtiyaç vardır.

Bulgulara göre öğrencilerin en fazla kullandığı sosyal medya sitesi Instagram olmakla birlikte gündem takibinde Facebook ilk sırada gelmektedir. Öğrencilerin referandum tarihini ilk öğrendikleri mecra ise televizyondur. Bunu yakın bir oranla internet takip etmektedir. Bu durumda internet ve sosyal ağlar daha yoğun kullanılmakla birlikte geleneksel mecralar içinde televizyon öne çıkmaktadır.

Referandum öncesi ve sonrası için öğrencilerin haber ve sosyal medya takibi sıklı̆̆ına bakıldığında referandum öncesinde haber takibinin, referandum sonrasında ise sosyal medya paylaşımlarının yoğun olduğu görülmektedir. Geleneksel mecralar arasında ayrım yapılmaksızın referandum öncesinde ilgili haberleri "her gün" ya da "sık sık" takip ettiğini söyleyen öğrencilerin oranı toplamda yaklaşı \%63 olup bu oran referandum sonrasında yaklaşık \%48’e düşmüştür. Sosyal medya paylaşım sıklığına dair bulgulara bakıldığında ise referandum öncesinde \%64 olan oranın referandum sonrasında yaklaşık \%68’e çıktığı görülmektedir. Bu durumun, referandum öncesindeki bilgilenme ihtiyacı ve referandum sonrasındaki duygu, düşünce paylaşımı isteğinden kaynaklandığını söylemek mümkündür. Geleneksel mecraların takibinde görülen azalma sosyal medya paylaşımlarında yaşanmamıştır. Bu durum, aslında gençlerin siyasal konularda dijital platformlardaki aktivelerde daha aktif oldukları yönündeki araştırma sonuçlarını da desteklemektedir.

Üniversite öğrencileri sosyopolitik gelişmeleri takip eden ve eleştiren bir sosyal grup içinde yer aldıklarından siyasal bilgiye ihtiyaç duyarlar. Seçim dönemleri, politik ilgi ve katılımın daha yüksek olmasının beklendiği bir dönemdir. Araştırma sonuçları (Delli Carpini ve Keeter, 1996; Jung, Kim, ve De Zúñiga, 2011) siyasal ilgi ve bilginin siyasal katılımı artırmada etkili olduğu yönündedir. Seçim dönemlerinde haber takibi için kitle iletişim araçlarının amaçlı kullanımı benzer düşüncedeki kişileri bir araya getiren ağların genişlemesine katkıda bulunabilir. Araştırma bulguları referandum öncesinde katılımcıların \%60'ından fazlasının hem geleneksel medyayı hem de sosyal medyayı siyasal gündem takibi için her gün ya da sık sık kullandığını göstermektedir. Bu oran, referandum sonrasında geleneksel medya için düşerken sosyal medya için yükselmiştir. Bu bakımdan yeni medya, gençlere ulaşmak için önemli bir firsat sunmakta olup özellikle kararsız seçmen açısından daha da öne çıkmaktadır. Çünkü araştırmanın bulguları, oy verme kararı almış öğrencilerin büyük oranda sandığa gittiğine buna karşın referandum öncesinde kararsızların oy vermemeyi tercih ettiğine işaret etmektedir.

Çalışmanın temel sorunsalı olan, çeşitli mecralardaki haberlerin referandum sürecinde oy verme/vermeme kararına etkisi olup olmadığı noktasında, katılımcıların büyük bir çoğunluğunun net bir tutum sergilediğini söylemek zordur. Zira katılımcıların, takip ettikleri iletişim mecralarından edindikleri haberlerin oy verme davranışları üzerindeki etkisine ilişkin görüşlerine yönelik soruya verilen cevaplardan, oy verme ya da karar değiştirmede bariz bir etkisinin olmadığı sonucuna ulaşılmıştır. Oy kullandığını söyleyen öğrenciler (305 kişi) ile referandum öncesinde oy kullanmayı düşündügünü söyleyen öğrencilerin (316 kişi) sayılarına bakıldığında 11 öğrencinin oy vermekten vazgeçtiği anlaşılmaktadır. Oy vermeyi düşünmediğini ifade eden öğrenciler (31 kişi) referandum sonrasında oy vermediğini söyleyen öğrencilerin (91 kişi) üçte biri kadardır. Referandum öncesinde 
oy verip vermemeye henüz karar vermediğini söyleyen öğrencilerin (49 kişi) çok büyük bir ihtimalle sandığa gitmedikleri anlaşılmaktadır. Bu sonuca göre, çalışmaya katılan öğrencilerin sosyal medyayı, gündem ve haber takibi için yoğun bir biçimde kullandıkları, bununla birlikte oy verme davranışının şekillenmesinde sosyal medyadan ya da diğer iletişim mecralarından etkilenme düzeylerinin sınırlı olduğunu söylemek mümkündür. Bir başka deyişle iletişim mecralarının öğrencilerin siyasal kararlara katılımına etkisi sınırlı kalmaktadır. Bu durum da sosyal medyanın siyasal katılıma etkisinin sınırlı olduğunu ortaya koyan Kushin ve Yamamoto’nun (2010) çalışma sonuçlarını desteklemektedir. Bu noktadan hareketle, gelecek dönemde bu durumu etkileyen değişkenlere yönelik araştırmalar yapılabilir.

Gençler özellikle de üniversite öğrencileri, geçmişten günümüze sosyal ve siyasal değişimde önemli aktörlerdirler. Siyasal süreçlerden gittikçe uzaklaştığı düşünülen üniversite gençliğinin farklı iletişim mecralarını nasıl değerlendirdiğini anlamak için yapılan çalışmalar bugün ve gelecek için önem taşımaktadır. Siyaset ile iletişimin kesişme noktasında bulunan ve aldıkları eğitimle gelecekte siyasal kampanyalar hazırlama ya da yürütme ihtimalleri yüksek olan iletişim fakültesi öğrencilerinin oy verme kararlarında, sosyal medya başta olmak üzere kitle iletişim araçlarının etkisini anlamak ise siyasal iletişimin rotasını çizmek açısından temel teşkil edecektir.

Araştırma örnekleminin sayısal büyüklüğü yeterli olmakla birlikte bu çalışmanın sonuçları yorumlanırken ve daha ileri araştırmalar yapılırken dikkate alınması gereken sınırlılıkların başında çalışmanın örneklem çeşitliliği gelmektedir. Araştırmanın amacı kapsamında sadece iletişim fakülteleri çalışmaya dahil edilmiştir. Araştırma iletişim fakültesi öğrencilerinin siyasal iletişim sürecindeki mecraları değerlendirme ve etkilenme düzeyleri ile bu dersleri almayan öğrencilerin karar ve davranışlarında farklılık olup olmadığının anlaşılması için diğer fakülte ve üniversitelere de genişletilebilir. Ayrıca ülkemizdeki seçmen davranışı üzerinde iletişim mecralarının etkisine dair daha fazla veri elde edebilmesi ve katılımı etkileyen değişkenlerin ortaya konulabilmesi amacıyla araştırmanın eğitim, yaş, sosyoekonomik durum gibi farklı özellikteki seçmenlere uygulanması da faydalı olacaktır. 


\section{Kaynakça}

Anık, C. (2000). Siyasal ikna. Ankara: Vadi Yayınları.

Atkin, C. ve Heald, G. (1976). Effects of political advertising. Public Opinion Quarterly, 40(2), 216-228.

Aydın, M. (2006). Siyasetin sosyolojisi: Bir sosyal kurum olarak siyaset. İstanbul: Açılım Kitap.

Balc1, Ş. ve Akar, H. (2010). Siyasal bilgilenmede iletişim araç ve yöntemlerinin önem düzeyi: 29 Mart 2009 yerel seçimleri Konya araştırması. E-Journal of New World Sciences Academy Humanities, 5(2), 282-305.

Balcı, Ş. ve Bor, T. (2015). Siyasal bilgilenmede televizyonun önem düzeyi. Global Media Journal, 5(10), 47-70.

Banaij, S. ve Buckingham, D. (2010). Young people, the internet, and civic participation: An overview of key findings from the CivicWeb project. International Journal of Learning and Media, 2(1), 1-24. DOI: 10.1162/ijlm_a_00038.

Baumgartner, J. C. ve Morris, J. S. (2010). MyFaceTube politics, social networking web sites and political engagement of young adults. SAGE. 28(1), 24-44.

Bayraktutan, G., Binark, M., Çomu, T., Doğu, B., İslamoğlu, G. ve Aydemir, A. (2014). Siyasal iletişim sürecinde sosyal medya ve Türkiye’de 2011 genel seçimlerinde Twitter kullanımı. Bilig, 68, 59-96.

Blais, A., Gidengil, E. ve Nevitte, N. (2004). Where does turnout decline come from? European Journal of Political Research, 43(2), 221-236. DOI: 10.1111/j.1475-6765.2004.00152.x.

Bode, L. ve Dalrymple, K. E. (2014). Politics in 140 characters or less: Campaign communication, network interaction, and political participation on Twitter. Journal of Political Marketing, 15(4), 1-22. DOI: 10.1080/15377857.2014.959686.

Brady, H., Verba, S. ve Schlozman, L. (1995). Beyond SES: A resource model of political participation. The American Political Science Review, 89(2), 271-294.

Burns, N., Schlozman, K. L. ve Verba, S. (2001). The private roots of public action: Gender, equality and political participation. MA: Cambridge: Harvard University Press.

Calenda, D. ve Meijer, A. (2009). Young people, the internet and political participation: Findings of a web survey in Italy, Spain and The Netherlands. Information, Communication \& Society, 12(6), 879-898.

Can, B. (2005). Bir siyasal iletişim aracı olarak televizyon (TBMM TV örneği). Communication and Media Studies in the Process of Social and Cultural Interaction (I. International Communication Symposium), Bishkek: Kyrgyz-Turkish Manas University Publications, 251-258.

Chun, S. A., Shulman, S., Sandoval, R. ve Hovy, E. (2010). Government 2.0: Making connections between citizens, data and government. Information Polity, 15, 1-9

Cotteret, J. M. ve Emeri, C. (1995). Seçim sistemleri. A. Kotil (Çev.). İstanbul: İletişim Yayınları.

Dalton, R. J. (2002). Citizen politics: Public opinion and political parties in advanced industrial democracies. London: Seven Bridges Press.

Damlapınar, Z. ve Balcı, Ş. (2005). Seçmenin zihnindeki aday imajını belirleyen etkenler: 28 Mart 2004 Yerel Seçimleri alan araştırması. Selçuk İletişim, 4(1), 58-79.

Damlapınar, Z. ve Balc1, Ş. (2014). Siyasal iletişim sürecinde seçimler, adaylar, imajlar. Konya: LiteraTürk Academia Yayınları.

De Zuniga, H., Jung, N. ve Valenzuela, S. (2012). Social media use for news and individuals' social capital, civic engagement and political participation. Journal of Computer-Mediated Communication, 17, 319-336. doi: 10.1111/j.1083-6101.2012.01574.

Della Porta, D. ve Mosca, L. (2005). Global-net for global movements? A network of networks for a movement of movements. Journal of Public Policy, 25(1), 165-190. 
Delli Carpini, M. X. ve Keeter, S. (1996). What Americans know about politics and why it matters? New Haven, CT: Yale University Press.

Di Gennaro, C. ve Dutton, W. (2006). The internet and the public: Online and offline political participation in the United Kingdom. Parliamentary Affairs, 59(2), 299-313.

Di Maggio, P., Hargittai, E., Neuman, R. ve Robinson, J. (2001). Social implications of the internet. Annual Review of Sociology, 27, 307-336.

Doğan, A. ve Göker, G. (2013). Genel seçimlerde seçmen tercihi: 12 Haziran 2011 Genel Seçimleri örnek olayı. A. Doğan ve G. Göker (Haz.), Siyasal iletişim araştırmaları içinde (s. 109-136). Ankara: Nobel Akademik Yayıncilık.

Ediraras, D. T., Rahayu, D. A., Natalina, A. ve Widya, W. (2013). Political marketing strategy of Jakarta Governor Election in the 2012. Procedia-Social and Behavioral Sciences, 81, 584-588. doi:10.1016/j. sbspro.2013.06.480.

Fama, P. A. ve Tam, C. M. (2010). From citizens to netizens: Social media and politics in Malaysia. P. Behke (Ed.), Social media and politics içinde (s. 79-85). Singapore: Konrad Adenauer Stiftung.

Fer, S. (2015). Young people's trends in political trust and views of their declining sense of duty. Journal of Identity and Migration Studies, 7(1), 111-132. DOI: 10.2139/ssrn.2574572.

Fieldhouse, E., Tranmer, M. ve Russell, A. (2007). Something about young people or something about elections? Electoral participation of young people in Europe: Evidence from a multilevel analysis of the European Social Survey. European Journal of Political Research, 46(6), 797-822. doi: 10.1111/j.14756765.2007.00713.x.

Gerbaudo, P. (2012). Tweets and the streets: Social media and contemporary activism. London: PlutoPress.

Global Overview Report (2017). 10.03.2017 tarihinde https://wearesocial.com/uk/ blog/2017/01/digital-in2017-global-overview adresinden edinilmiştir.

Güz, N. (1995). Siyasal tercihleri belirlemede kitle iletişim araçlarının rolü (Mart 1994 Yerel Seçimleri Ankara Örneği). Amme İdaresi Dergisi, 28(1), 113-128.

Güz, N. (1996). Türk basınında gündem oluşturma. Yeni Türkiye Dergisi, Medya Özel Sayısı, 2(12), 982-997.

Jung, N., Kim, Y. ve De Zúñiga, H. G. (2011). The mediating role of knowledge and efficacy in the effects of communication on political participation. Mass Communication and Society, 14(4), 407-430. DOI:10.1 080/15205436.2010.496135.

Kaid, L. L. ve Holtz-Bacha, C. (2008). Encyclopedia of political communication. California: Sage Publication.

Kaid, L. L., McKinney, M. S. ve Tedesco, J. C. (2007). Introduction: Political information efficacy and young voters. American Behavioral Scientist, 50(9), 1093-1111. DOI: 10.1177/0002764207300040i.

Kalaycıoğlu, E. (1983). Karşılaştırmal siyasal katılma siyasal eylemin kökenleri üzerine bir inceleme. İstanbul Üniversitesi Siyasal Bilimler Fakültesi Yayınları, No:10.

Kalender, A. (2003). Seçmenin karar verme sürecinde iletişim araç ve yöntemlerinin önemi üzerine bir araştırma. Selçuk İletişim, 2(4), 30-41.

Karaçor, S. (2013). Seçmen siyasal kampanyalardan ne bekler? Konya: Çizgi Kitabevi Yayınları.

Kenski, K. ve Stroud, N. J. (2006). Connections between internet use and political efficacy, knowledge, and participation. Journal of Broadcasting Electronic Media, 50(2), 173-192. DOI: 10.1207/ s15506878jobem5002_1.

Kraus, S. ve Davis, D. (1978). The effect of mass communication on political behavior. Pennsylvania: The Pennsylvania State University Press. 
Kushin, M. J. ve Yamamoto, M. (2010). Did social media really matter? College students' use of online media and political decision making in the 2008 election. Mass Communication and Society, 13(3), 608630. DOI: 10.1080/15205436.2010.516863.

Lilleker, D. G. ve Koc-Michalska, K. (2017). What drives political participation? Motivations and mobilization in a digital age. Political Communication, 34(1), 21-43. DOI: 10.1080/10584609.2016.1225235.

Livingstone, S. ve Bovill, M. (1999). Children, young people and the changing media environment. London School of Economics and Political Science Report of the Research Project.

Lundby, K. ve Ronning H. (1997). Medya kültür iletişim: Medya kültürü aracılı̆̆ıyla modernliğin yorumlanışı. S. İrvan (Editör). Medya, kültür, siyaset içinde (s. 13-28). Ankara: Ark Yayınları.

Martin, A. (2012). Young people and politics: Political engagement in the Anglo-American democracies. London, UK: Routledge.

McNair, B. (1995). An introduction to political communication. London: Routledge.

Mindich, D. T. (2005). Tuned out: Why Americans under 40 don't follow the news. Oxford: Oxford University Press.

Mujani, S. ve Liddle, R.W. (2010, March 9). Personalities, parties, and voters. 10.03.2017 tarihinde http://www.lsi. or.id/riset/384/Journal\%20of\%20Democracy\%20 Mujani \%20and\%20Liddie adresinden edinilmiștir.

Norris, P. (2002). Democratic phoenix: Political activism worldwide. New York: Cambridge University Press.

Oppenhuis, E. (1995). Voting behavior in Europe: A comparative analysis of electoral participation and party choice. Amsterdam: Het Spinhuis.

Owen, D. ve Dennis, J. (1992). Sex differences in politicization: The influence of mass media. Women and Politics, 12 (1), 19-41.

Sarıbay, A. Y. (1994). Siyasal sosyoloji. İstanbul: Der Yayınları.

Shah, D. V., Kwak, N. ve Holbert, R. L. (2001). 'Connecting' and 'disconnecting' with civic life: Patterns of internet use and the production of social capital. Political Communication, 18(2), 141-162.

Spada, P., Mellon, J., Peixoto, T. ve Sjoberg, F. (2016). Effects of the internet on participation: Study of a public policy referendum in Brazil. Journal of Information Technology \& Politics, 13(3), 187-207.

Stanley, J. W. ve Weare, C. (2004). The effects of internet use on political participation. evidence from an agency online discussion forum. Administration \& Society, 36(5), 503-527. DOI: 10.1177/0095399704268503.

Strandberg, K. (2013). A social media revolution or just a case of history repeating itself? The use of social media in the 2011 Finnish parliamentary elections. New Media \& Society, 15(8), 1329-1347. DOI: $10.1177 / 1461444812470612$.

Sweetser, K. D. ve Lariscy, R. W. (2008). Candidates make good friends: An analysis of candidates' uses of Facebook. International Journal of Strategic Communication, 2(3), 175-198. DOI: 10.1080/15531180802178687.

Tokgöz, O. (1978). Siyasal toplumsallaşmada kitle haberleşme araçlarının rolü ve önemi. Ankara Üniversitesi Siyasal Bilgiler Fakültesi Dergisi, 23(3-4), 79-92.

Tongut, S. ve Akman, E. (2014). Sosyal medyanın siyasi partiler tarafından siyasal iletişim aracı olarak kullanılması: 2014 Yerel Seçimleri ve Cumhuriyet Halk Partisi İstanbul Büyükşehir Belediye Başkan Adayı Mustafa Sarı̈ül'ün Twitter kullanımı. Turkish Studies, 9(5), 117-137.

Touraine, A. (2002). Eşitlik ve farklılıklarımızla birlikte yaşayabilecek miyiz? O. Kunal (Çev.). İstanbul: YKY Yayınları.

Trent, J. ve Friedenberg, R. (1983). Political campaign communication. New York: Preager.

Turan, İ. (1986). Siyasal sistem ve siyasal davranış. İstanbul: Der Yayınları. 
TÜİK (Türkiye İstatistik Kurumu) Hanehalkı Bilişim Teknolojileri Kullanım Araştırması (2016). 31.03.2017 tarihinde www.tuik.gov.tr/PreHaberBultenleri. do?id=21779 adresinden edinilmiştir.

Twenge, J. M. (2009). Ben nesli E. Öztürk (Çev.). İstanbul: Kaknüs Yayınları.

Uztuğ, F. (2004). Siyasal iletişim yönetimi. İstanbul: MediaCat Kitapları.

Vitak, J., Zube, P., Smock, A., Carr, C. T., Ellison, N. ve Lampe, C. (2011). It's complicated: Facebook users' political participation in the 2008 election. Cyberpsychology, Behavior and Social Networking, 14(3), 10714. DOI: 10.1089/cyber.2009.0226.

Wilkins, K. G. (2000). The role of media in public disengagement from political life. Journal of Broadcasting \& Electronic Media, 44(4), 569-580. DOI: 10.1207/s15506878jobem4404_3.

Yamamoto, M., Kushin, M. J. ve Dalisay, F. (2013). Social media and mobiles as political mobilization forces for young adults: Examining the moderating role of online political expression in political participation. New Media \& Society, 1, 1-19. DOI: 10.1177/1461444813518390.

Yazıcıoğlu, Y. ve Erdoğan, S. (2004). SPSS uygulamalı bilimsel araştırma yöntemleri. Ankara: Detay Yayıncılık.

Yıldız, N. (2002). Türkiye'de siyasetin yeni biçimi: Liderler majlar medya. Ankara: Phoenix Yayınevi.

Yükseköğretim Kurulu (YÖK) İstatistikleri (2017). 02.04.2018 tarihinde https://istatistik.yok.gov.tr adresinden edinilmiştir.

Zhang, W., Seltzer, T. ve Bichard, S. L. (2013). Two sides of the coin: Assessing the influence of social network Site use during the 2012 U.S. presidential campaign. Social Science Computer Review, 31(5), 542-551. DOI:10.1177/0894439313489962. 